\title{
Impact of Thawing Methods on the Bacteriological Quality of Chicken Meat
}

\author{
Dina H Mahmoud ${ }^{1}$, Heba B Mahmoud ${ }^{2}$, Fathi AM EL-Nawawi ${ }^{1}$ and Heba HS Abdel-Naeem ${ }^{1 *}$ \\ ${ }^{1}$ Department of Food Hygiene and Control, Faculty of Veterinary Medicine, Cairo University, Giza, Egypt \\ ${ }^{2}$ Department of Microbiology-(RLVQCPP), Animal Health Research Institute, Ministry of Agriculture, Giza, Egypt \\ *Corresponding author: h.hussein@cu.edu.eg; dr_hoba.h106@yahoo.com
}

\begin{tabular}{l} 
Article History: $20-225 \quad$ Received: $31-O c t-20 \quad$ Revised: $18-J a n-21$ \\
\hline A BSTRACT \\
This study was designed to investigate the effect of different thawing methods on the bacteriological quality of frozen \\
broiler chicken meat. Forty-five samples of whole frozen broiler chicken carcasses were collected from different \\
supermarkets in Cairo and Giza governorates. These samples were divided into three groups (fifteen samples for each) \\
as follows: the first group was thawed in a household refrigerator at $7^{\circ} \mathrm{C}$ for $20 \mathrm{hrs}$. , the $2^{\text {nd }}$ group was thawed over the \\
counter-top at ambient temperature $\left(27-29^{\circ} \mathrm{C}\right)$ for $5-6 \mathrm{hrs}$. while, the $3^{\text {rd }}$ group was thawed in microwave oven for 22 to \\
24 mins. All thawed samples (core temperature arrived at $\left.0^{\circ} \mathrm{C}\right)$ were subjected to bacteriological examination \\
immediately after thawing for enumeration of total aerobic mesophilic bacterial count, Staph. aureus count, total \\
Coliforms count and isolation of food borne pathogens such as E. coli, Salmonella and Staph. aureus. In addition, all \\
isolated bacterial strains were exposed to antimicrobial sensitivity test. The results revealed that the lowest bacterial \\
counts were observed in samples thawed in microwave oven, while the highest bacterial counts were recorded in samples \\
thawed over counter-top. Moreover, Staph. aureus, E. coli and S. kentucky were isolated only from samples thawed over \\
the counter-top and these strains were resistant to amoxicillin and sensitive to fosfomycin. Such results indicated that \\
defrosting in microwave oven is quick and easy method for thawing frozen broiler chicken carcasses and provides an \\
appropriate level of security for the consumers and could achieve the microbiological safety objectives while, thawing \\
over counter-top not recommended due to food safety and quality aspect.
\end{tabular}

Key words: Thawing, Refrigerator, Counter-top, Microwave, Chicken meat, Bacteriological quality.

@202I IJVS - All Rights Reserved

\section{INTRODUCTION}

Broiler chicken meat provide animal protein for consumers of all ages, which has high biological value, where they contain all the essential amino acids required for growth with low cholesterol level and high percent of unsaturated fatty acids. Moreover, chicken meat contains different vitamins as riboflavin, thiamine, niacin and ascorbic acid as well as phosphorus, sulphar, iodine, sodium, calcium and iron (Abou-Hussein 2007). However, chicken meat can perish rapidly if it is not stored, processed, packaged or distributed correctly (EFSA 2013). It can be spoiled by microbial activity or through the oxidative processes due to the high content of polyunsaturated fatty acids resulting in undesirable changes which make this meat unattractive and unfit for human consumption (Bosco et al. 2016).

Freezing delay, the microbial growth, metabolic activities and chemical reactions, and preserve the quality of chicken meat until it reaches the consumer. However, the correct thawing practice should also be selected in order to ensure the quality of the final product. Not only consumers at home or food chain restaurants are depending on the thawed chicken meat during preparation of chicken meals but also thawing process is very essential step for poultry meat industries during processing. In this regard, it is of importance to stipulate that during thawing, chicken meat is subjected to microbial growth, chemical deterioration and excessive loss of water caused by dehydration or dripping. This may be due to the softer and thinner characteristics of the muscle fibers of poultry meat as compared with that of livestock (Akhtar et al. 2013; Sulleyman et al. 2018; Mehmood et al. 2020; El Jalil et al. 2020). Moreover, consumer awareness toward consuming high quality safe food has been increased. Therefore, it is important to choose suitable thawing method with minimum time consuming in order to obtain good quality safe chicken meat with technological properties closest to the refrigerated one.

Cite This Article as: Mahmoud DH, Mahmoud HB, EL-Nawawi FAM and Abdel-Naeem HHS, 2021. Impact of thawing methods on the bacteriological quality of chicken meat. International Journal of Veterinary Science 10(3): 214-219. https://doi.org/10.47278/journal.ijvs/2021.041 
There are various thawing methods for meat such as using cold air circulation (home refrigerators), immersion in cold water, thawing at room temperature (counter-top) and thawing in slightly warmed air (heater) in a microwave oven. Thawing of food, such as chicken meat in the refrigerator is better to preserve its natural juice, flavor and texture. However, this technique is inefficient, consuming time, and occupying more space required for chilling of other food items. In addition, it can make cross-contamination with the refrigerated ready-to-eat food if it comes in contact with the drip of thawed meat. Thawing of chicken carcass in the refrigerator takes about 1-2 days depending on its weight (about 5hrs/half kg) (Xia et al. 2012).

Unfortunately, many consumers are favoring to thaw meat at room temperature (counter-top) due to its simplicity. However, this technique can poses serious health risks and impairs product quality. In addition, thawing at room temperature increases the drip loss which leads to less acceptability due to the loss of the tasteful constituents and it is not suggested by the food codes and regulation due to the risk of microbial spoilage (Met et al. 2013). Using of microwave oven as an easy and quick thawing method for frozen meat has become increasingly applied in both households and in industry due to its speediness and the microbiological safety concern. However, the thawed meat by this technique should be immediately cooked (Krifi et al. 2014).

Most of previous studies are focused on effect of different thawing methods on the physicochemical and structural characteristics of chicken meat (Oliveira et al. 2015; Zhang et al. 2017). However, there is lack of information concerning evaluation of different thawing methods on bacteriological quality of chicken meat. Moreover, assessment of the bacterial status of poultry meat has an important role in assuring the best thawing method which affects the quality of poultry meat. Therefore, the aim of this study was to evaluate the effect of different thawing methods (household refrigerator, counter-top in the kitchen and microwave oven) on the bacteriological quality of frozen broiler chicken meat.

\section{MATERIALS AND METHODS}

\section{The Study Design}

A three independent replicates at different times (5 samples for each replicate) were conducted to investigate the effect of different thawing methods (household refrigerator, counter-top in the kitchen and microwave oven) on the bacteriological quality of frozen broiler chicken carcasses.

\section{Collection of Samples and Application of Different Thawing Methods}

Whole frozen broiler chicken carcasses (1000-1200g net weight), of the first $3^{\text {rd }}$ of its shelf life, while being stored at $-10^{\circ} \mathrm{C}$ were obtained from Cairo and Giza stores and transferred directly to the Reference Laboratory for Veterinary Quality Control on Poultry production (RLVQCPP), Animal Health Research Institute, Agriculture Research Center, Ministry of Agriculture, Egypt. These samples were divided into three groups (fifteen samples for each) as follows: the first group was thawed in a household refrigerator at $7^{\circ} \mathrm{C}$ for $20 \mathrm{hrs}$., the $2^{\text {nd }}$ group was thawed over the counter-top in the kitchen at ambient temperature of (27$29^{\circ} \mathrm{C}$ ) for 5-6hrs. while, the $3^{\text {rd }}$ group was thawed (Weight Defrost) in microwave oven (ZANUSSI, ZMW43FGCXA), at a rated output of $1000 \mathrm{~W}$ for 22 to 24 mins. Such defrost setting lowers the appliance power between 30 to $50 \%$ to arrive an internal temperature of $0^{\circ} \mathrm{C}$ within few mins. (2224 mins.) depending on the weight of the frozen broiler's chicken (1000-1200g), without cooking the defrosted meat. Therefore, such defrosted samples should be processed or cooked immediately after defrosting.

Frozen chicken carcasses were kept in refrigerator, over the counter-top and in microwave oven until complete thawing and the core temperature arrived at $0^{\circ} \mathrm{C}$. All thawed frozen chicken samples were subjected to bacteriological examination for enumeration of total aerobic mesophilic bacterial count, Staph. aureus count, total Coliforms count and isolation of food borne pathogens such as E. coli, Salmonella and Staph. aureus. In addition, all isolated bacterial strains were exposed to antimicrobial sensitivity test.

\section{Investigations Bacteriological Examination}

Double sets of inoculated Standard Plate Count Agar plates (Oxoid CM 463) were incubated at $30^{\circ} \mathrm{C}$ for $48 \mathrm{hrs}$ for enumeration of total aerobic mesophilic bacteria according to ISO-4833 (2013). While for counting of Staph. aureus, double sets of inoculated Baird Parker Agar plates (Oxoid CM 145) were incubated at $37^{\circ} \mathrm{C}$ for $48 \mathrm{hrs}$ and the suspected colonies of Staph. aureus were biochemically and serologically identified (ISO-6888, 2018). For enumeration of total Coliforms count, double sets of the inoculated Violet Red Bile Glucose agar (Oxoid $\mathrm{CM} 485$ ) were incubated at $30^{\circ} \mathrm{C}$ for $24 \mathrm{hrs}$. (ISO-4832, 2006). For isolation of E. coli, loopful from each of the positive $E$. coli broth tube was inoculated over the surface of Eosin Methylene Blue (EMB) agar plates and the suspected colonies of $E$. coli were biochemically and serologically identified (Krieg and Holt 1984). Salmonella isolation was carried out by streaking onto each of XyloseLysine Desoxycholate (XLD) and MacConkey. The suspected colonies of Salmonella were biochemically and serologically identified according to the procedure recommended by ISO-6579 (2002).

\section{Antimicrobials Sensitivity Test}

All isolated bacterial strains were exposed to antimicrobials sensitivity test using disk diffusion method which applied according to Koneman et al. (1979).

\section{Statistical Analysis}

All data were analyzed using SPSS statistics 17.0 for windows, expressed as means \pm SE and compared using one-way analysis of variance (ANOVA). The significance was determined using least square difference test (LSD) procedure and the main effects were considered significance at the $\mathrm{P}<0.05$ level.

\section{RESULTS AND DISCUSSION}

\section{Bacteriological Examination}

Total aerobic mesophilic bacterial count and total Coliforms counts, are the most reliable index of meat quality, sanitary processing and shelf- life of meat. In addition, Staph. aureus, Salmonella and E. coli are reflecting 
Int J Vet Sci, 2021, 10(3): 214-219.

Table 1: Bacterial counts ( $\log _{10} \mathrm{CFU} / \mathrm{g}$ ) of frozen chicken carcasses thawed with different thawing methods

\begin{tabular}{lccc}
\hline Bacterial counts & \multicolumn{3}{c}{ Thawing Methods } \\
\cline { 2 - 4 } & Microwave $(\mathrm{n}=15)$ & Counter-top $(\mathrm{n}=15)$ & Refrigerator $(\mathrm{n}=15)$ \\
\hline Total aerobic mesophilic bacterial & $3.71 \pm 0.16 \mathrm{a}$ & $3.57 \pm 0.14 \mathrm{a}, \mathrm{b}$ & $3.20 \pm 0.16 \mathrm{~b}$ \\
Staph. Aureus & $<2 \pm 0.00 \mathrm{a}$ & $<2 \pm 0.00 \mathrm{a}$ & $<2 \pm 0.00 \mathrm{a}$ \\
Total Coliforms & $1.22 \pm 0.47 \mathrm{a}, \mathrm{b}$ & $2.29 \pm 0.44 \mathrm{a}$ & $0.91 \pm 0.41 \mathrm{~b}$ \\
\hline
\end{tabular}

Values (Mean+SE) bearing different alphabets within a row differ significantly $(\mathrm{P}<0.05)$.

food safety concern (ICMSF 1980). The results of bacterial counts $\left(\log _{10} \mathrm{CFU} / \mathrm{g}\right)$ of frozen chicken carcasses thawed with refrigerator, counter-top and microwave were presented in Table 1. Total aerobic mesophilic bacterial count was significantly $(\mathrm{P}<0.05)$ lower $\left(3.20 \log _{10} \mathrm{CFU} / \mathrm{g}\right)$ in frozen chicken meat samples thawed by microwave while the non-significant $(\mathrm{P}>0.05)$ higher value $\left(3.71 \log _{10}\right.$ $\mathrm{CFU} / \mathrm{g}$ ) was observed in frozen chicken meat samples thawed by refrigerator as compared with frozen chicken carcasses thawed over counter-top (3.57 $\log _{10} \mathrm{CFU} / \mathrm{g}$ ). On the other hand, Staph. aureus count was under the detectable limit $\left(<2 \log _{10} \mathrm{CFU} / \mathrm{g}\right)$ in frozen chicken meat samples thawed by refrigerator, microwave and over the counter-top. Total Coliforms count was significantly $(\mathrm{P}<0.05)$ lower $\left(0.91 \log _{10} \mathrm{CFU} / \mathrm{g}\right)$ in frozen chicken meat samples thawed by microwave while the highest value (2.29 $\log _{10} \mathrm{CFU} / \mathrm{g}$ ) was recorded in frozen chicken meat samples thawed over the counter.

The obtained results concerning the non-significant higher total aerobic mesophilic bacterial count of frozen chicken carcasses thawed by refrigerator as compared with samples thawed over counter-top may be due to high drip loss resulting from long time of thawing (20hrs.) in refrigerator as compared with over counter-top (5-6hrs.) which considered good media for growth of microorganism. This finding was also confirmed by Ambrosiadis et al. (1994) who found that thawing using refrigerator for $28 \mathrm{hrs}$. resulted in the highest drip loss than microwave thawing for 35 mins. and ambient air thawing for 5-7hrs. However, Belletti et al. (2007) found that thawing by refrigerator is the best thawing method of frozen minced red meat as compared with thawing under tap water or at room temperature where it could reduce the bacterial counts $\left(3.55 \log _{10} \mathrm{CFU} / \mathrm{g}\right.$ ) as compared to tap water (4.10 $\log _{10} \mathrm{CFU} / \mathrm{g}$ ) and room temperature (4.62 $\log _{10}$ $\mathrm{CFU} / \mathrm{g}$ ). In addition, Erdem et al. (2014) recorded that thawing of frozen minced red meat by refrigerator for overnight produce meat of high stable microbiological quality.

The obtained results of bacterial counts of frozen chicken carcasses thawed by refrigerator and microwave were in agreement with the findings of Krifi et al. (2014) who found that microwave thawing process was faster than thawing by refrigerator; however, both methods fulfilled the standard requirements for total aerobic mesophilic bacterial counts and Staph. aureus counts. The lowest bacterial counts of frozen chicken carcasses thawed by microwave may be due to the lethal effect of microwave on the growth of microorganisms (Mansouri 2012; Orlova et al. 2020). Meanwhile, the highest bacterial counts of frozen chicken meat thawed over counter-top was in agreement with the findings of $\mathrm{He}$ et al. (2013) who observed that thaw of meat at relatively high temperatures $\left(20-30^{\circ} \mathrm{C}\right)$ as in room temperature may contribute to microbial growth and produce unacceptable meat. This result was explained by Leygonie et al. (2012) and Akhtar et al. (2013) who found that thawing of meat at room temperature will be exposed to more favorable high temperature conditions, the slower and less uniform thawing with increase the moisture and nutrients from drip loss provides an excellent medium for microbial growth.

It is important to notice that thawed chicken carcass has no Egyptian Standards (ES) legislation, and the obtained results could be evaluated according to ES for frozen chicken carcass (ES 1090/2005), chilled chicken carcass (ES 1651/2005) or with the previous published literature. The mean values of total aerobic mesophilic bacterial counts of the frozen chicken carcasses thawed by refrigerator, over counter-top and microwave were within the recommended limit (not more than $5 \log _{10} \mathrm{CFU} / \mathrm{g}$ ) described by ES 1090/2005 for frozen chicken carcass and ES 1651/2005 for chilled chicken carcass. Both Staph. aureus counts and total Coliforms counts were not mentioned in ES 1090/2005 for frozen chicken carcass while the permissible limit of total Coliforms counts (not more than $2 \log _{10} \mathrm{CFU} / \mathrm{g}$ ) was mentioned only in ES $1651 / 2005$ for chilled chicken carcass. Total Coliforms count in chicken meat thawed over counter-top is considered high according to the permissible limit described by ES 1651/2005 for chilled chicken and the previous literature (Hassanien et al. 2016) which indicate the unfavorable hygienic conditions and fecal contamination in foods. While total Coliforms counts were within the permissible limit in samples thawed by refrigerator and microwave. The percentages of accepted and rejected frozen chicken meat samples thawed by different thawing methods according to ES 1090/2005 for frozen chicken and ES 1651/2005 for chilled chicken were summarized in Table 2. The percentage of rejected frozen chicken meat samples was $0 \%$ in all frozen chicken meat samples thawed by refrigerator, counter-top and microwave for total aerobic mesophilic bacterial count. While the percentage of rejected frozen chicken meat samples thawed by refrigerator, counter-top and microwave oven was $33.33,66.6$ and $26.67 \%$ for total Coliforms count.

At the same time, Staph. aureus, E. coli poly ${ }_{2} \mathrm{O}_{125}, E$. coli poly ${ }_{2}: \mathrm{O}_{44}$ and $\mathrm{S}$. kentucky strains were isolated from only frozen chicken meat samples thawed over counter-top with incidence 20,6.67, 13.33 and $6.67 \%$, respectively. However, these strains failed to be isolated from frozen chicken meat samples thawed by refrigerator, and microwave (Table 3). It is important to point out that frozen chicken (ES 1090/2005) should be free from E. coli and Salmonellae. The obtained results concerning the absence of Staph. aureus, E. coli and Salmonella strains in microwave thawed samples may be due to heat waves arise from it, the short time required for thawing and very little drip obtained which give no chance for the microorganism to grow. The absence of $E$. coli strain from frozen chicken 
Int J Vet Sci, 2021, 10(3): 214-219.

Table 2: The percentage of accepted and rejected frozen chicken carcasses thawed with different thawing methods (in refrigerator, on counter top and in microwave oven)

\begin{tabular}{|c|c|c|c|c|c|c|c|}
\hline \multirow[t]{3}{*}{ Bacterial Counts } & \multirow[t]{3}{*}{$\left(\log _{10} \mathrm{CFU} / \mathrm{g}\right)$} & \multicolumn{6}{|c|}{ Thawing Methods } \\
\hline & & \multicolumn{2}{|c|}{ Refrigerator $(n=15)$} & \multicolumn{2}{|c|}{ Counter-top $(n=15)$} & \multicolumn{2}{|c|}{ Microwave $(n=15)$} \\
\hline & & No. & $\%$ & No. & $\%$ & No. & $\%$ \\
\hline \multirow[t]{2}{*}{ Total aerobic mesophilic bacterial count } & $<5$ (accepted) & 15 & 100 & 15 & 100 & 15 & 100 \\
\hline & $>5$ (rejected) & 0 & 0 & 0 & 0 & 0 & 0 \\
\hline \multirow[t]{2}{*}{ Total Coliforms } & $<2$ (accepted) & 10 & 66.67 & 5 & 33.33 & 11 & 73.33 \\
\hline & $>2$ (rejected) & 5 & 33.33 & 10 & 66.67 & 4 & 26.67 \\
\hline
\end{tabular}

Table 3: Incidence (\%) of pathogens in frozen chicken carcasses thawed with different thawing methods (in refrigerator, on counter-top and in microwave oven)

\begin{tabular}{|c|c|c|c|c|c|c|}
\hline \multirow[t]{3}{*}{ Organisms } & \multicolumn{6}{|c|}{ Thawing Methods } \\
\hline & \multicolumn{2}{|c|}{ Microwave $(n=15)$} & \multicolumn{2}{|c|}{ Counter-top $(n=15)$} & \multicolumn{2}{|c|}{ Refrigerator $(n=15)$} \\
\hline & No. & $\%$ & No. & $\%$ & No. & $\%$ \\
\hline Staph. Aureus & Negative & 0 & 3 & 20 & Negative & 0 \\
\hline E. coli E. coli poly2: $O_{125}$ & Negative & 0 & 1 & 6.67 & Negative & 0 \\
\hline E. coli poly $2: \mathrm{O}_{44}$ & Negative & 0 & 2 & 13.33 & Negative & 0 \\
\hline Salmonella $S$. kentucky & Negative & 0 & 1 & 6.67 & Negative & 0 \\
\hline
\end{tabular}

carcasses thawed by microwave was in agreement with the findings of Woo et al. (2000) and Jamshidi et al. (2010). While, failure for isolation of Salmonella from frozen chicken carcasses thawed by microwave and refrigerator was in agreement with Krifi et al. (2014). In addition, Schnepf and and Barbeau (2007) observed that microwave radiation of fresh whole roasting chickens with internal temperature $85^{\circ} \mathrm{C}$ could eliminate $S$. Typhimurium. Contrary to the obtained result, Farber et al. (1998) isolated Salmonella strains from food heated in microwave ovens and explained its survival rate to the non-uniform heating and their asymmetrical form.

It was noticed from the achieved results that using of microwave is the best method for thawing of frozen chicken meat which give the lower bacterial counts with absent of food borne pathogens such as Staph. aureus, E. coli and Salmonella followed by using of refrigerator. While, thawing of frozen chicken carcasses over countertop is not suitable as it affect the quality and safety of chicken meat. However, Gilbert et al. (2007) found that the most preferred method for defrosting frozen meat and poultry at home in New Zealand was thawing at room temperature for $12 \mathrm{hrs}$. Meanwhile, Ordóñez et al. (2005) observed that in order to ensure final product quality the appropriate thawing methods should be considered and recommended thawing of meat slowly at low temperatures. While, USDA-FSIS stated that thawing of the frozen meat in refrigerator, cold water, and microwave are three safe ways for thawing however, thawing in hot water and over the counter-top are not suggested.

\section{Antimicrobials sensitivity test}

Antimicrobials sensitivity test of Staph. aureus, E. coli and $S$. kentucky isolated from frozen chicken carcasses thawed over counter-top were presented in Table 4, 5 and 6. The results of sensitivity test for the isolated Staph. aureus (3 strains) showed that these strains were sensitive to seven antimicrobials (streptomycin, doxycycline, trimethoprim, clindamycin, fosfomycin, ciprofloxacin and oxytetracycline) and resistant to four antimicrobials (colistinsulphate, penicillin $\mathrm{G}$, amoxicillin and ampicillin) with percentage $100 \%$. While, two strains were resistant to gentamycin with percentage $66.6 \%$ and only one strain was sensitive to gentamycin and resistant to erythromycin with
Table 4: Antimicrobial sensitivity test of Staph. aureus isolated from frozen chicken carcasses thawed over counter-top

\begin{tabular}{|c|c|c|c|c|c|c|}
\hline \multirow{3}{*}{$\begin{array}{l}\text { Antimicrobial } \\
\text { discs }\end{array}$} & \multicolumn{6}{|c|}{ Sensitivity of Staph. aureus isolates $(n=3)$} \\
\hline & \multicolumn{2}{|c|}{ Sensitive } & \multicolumn{2}{|c|}{ Intermediate } & \multicolumn{2}{|c|}{ Resistance } \\
\hline & No & $\%$ & No & $\%$ & No & $\%$ \\
\hline Erythromycin & 0 & 0 & 2 & 66.6 & 1 & 33.3 \\
\hline Streptomycin & 3 & 100 & 0 & 0 & 0 & 0 \\
\hline Doxycycline & 3 & 100 & 0 & 0 & 0 & 0 \\
\hline Trimethoprim & 3 & 100 & 0 & 0 & 0 & 0 \\
\hline Clindamycin & 3 & 100 & 0 & 0 & 0 & 0 \\
\hline Fosfomycin & 3 & 100 & 0 & 0 & 0 & 0 \\
\hline Ciprofloxacin & 3 & 100 & 0 & 0 & 0 & 0 \\
\hline Gentamycin & 1 & 33.3 & 0 & 0 & 2 & 66.6 \\
\hline Colistinsulphate & 0 & 0 & 0 & 0 & 3 & 100 \\
\hline Penicillin G & 0 & 0 & 0 & 0 & 3 & 100 \\
\hline Oxytetracycline & 3 & 100 & 0 & 0 & 0 & 0 \\
\hline Amoxicillin & 0 & 0 & 0 & 0 & 3 & 100 \\
\hline Ampicillin & 0 & 0 & 0 & 0 & 3 & 100 \\
\hline
\end{tabular}

Table 5: Antimicrobial sensitivity test of E. coli isolated from frozen chicken carcasses thawed over counter-top

\begin{tabular}{|c|c|c|c|c|c|c|}
\hline \multirow{3}{*}{$\begin{array}{l}\text { Antimicrobial } \\
\text { discs }\end{array}$} & \multicolumn{6}{|c|}{ Sensitivity of $E$. coli isolates $(\mathrm{n}=3)$} \\
\hline & \multicolumn{2}{|c|}{ Sensitive } & \multicolumn{2}{|c|}{ Intermediate } & \multicolumn{2}{|c|}{ Resistance } \\
\hline & No & $\%$ & No & $\%$ & No & $\%$ \\
\hline Erythromycin & 0 & 0 & 0 & 0 & 3 & 100 \\
\hline Streptomycin & 0 & 0 & 0 & 0 & 3 & 100 \\
\hline Doxycycline & 2 & 66.6 & 1 & 33.3 & 0 & 100 \\
\hline Trimethoprim & 1 & 33.3 & 0 & 0 & 2 & 66.6 \\
\hline Clindamycin & 0 & 0 & 0 & 0 & 3 & 100 \\
\hline Fosfomycin & 3 & 100 & 0 & 0 & 0 & 0 \\
\hline Ciprofloxacin & 2 & 66.6 & 0 & 0 & 1 & 33.3 \\
\hline Gentamycin & 1 & 33.3 & 0 & 0 & 2 & 66.6 \\
\hline Colistinsulphate & 3 & 100 & 0 & 0 & 0 & 0 \\
\hline Oxytetracycline & 2 & 66.6 & 0 & 0 & 1 & 33.3 \\
\hline Amoxicillin & 0 & 0 & 0 & 0 & 3 & 100 \\
\hline Ampicillin & 0 & 0 & 0 & 0 & 3 & 100 \\
\hline
\end{tabular}

a percentage $33.3 \%$ (Table 4). Islam et al. (2014) recorded that the isolated Staph. aureus strains from frozen chicken meat were resistant to ampicillin with percentage $100 \%$, oxytetracycline, doxycycline hydrochloride and amoxicillin with percentage more than $80 \%$, ciprofloxacin, cephalexin and gentamycin with percentage $77.5 \%$, $38.33 \%$ and $13.33 \%$, respectively.

Concerning the isolated $E$. coli strains (one strain of $E$. coli poly $y_{2} \mathrm{O}_{125}$ and two strains of $E$. coli poly : $_{44}$ ) from frozen chicken meat thawed over counter-top, all these 
Table 6: Antimicrobial sensitivity test of $S$. kentucky isolated from frozen chicken carcasses thawed over counter-top

\begin{tabular}{|c|c|c|c|c|c|c|}
\hline \multirow{3}{*}{$\begin{array}{l}\text { Antimicrobial } \\
\text { discs }\end{array}$} & \multicolumn{6}{|c|}{ Sensitivity of $S$. kentucky isolate $(\mathrm{n}=1)$} \\
\hline & \multicolumn{2}{|c|}{ Sensitive } & \multicolumn{2}{|c|}{ Intermediate } & \multicolumn{2}{|c|}{ Resistance } \\
\hline & No & $\%$ & No & $\%$ & No & $\%$ \\
\hline Erythromycin & 0 & 0 & 0 & 0 & 1 & 100 \\
\hline Streptomycin & 1 & 100 & 0 & 0 & 0 & 0 \\
\hline Doxycycline & 1 & 100 & 0 & 0 & 0 & 0 \\
\hline Trimethoprim & 1 & 100 & 0 & 0 & 0 & 0 \\
\hline Clindamycin & 0 & 0 & 0 & 0 & 1 & 100 \\
\hline Fosfomycin & 1 & 100 & 0 & 0 & 0 & 0 \\
\hline Ciprofloxacin & 1 & 100 & 0 & 0 & 0 & 0 \\
\hline Gentamycin & 1 & 100 & 0 & 0 & 0 & 0 \\
\hline Colistinsulphate & 1 & 100 & 0 & 0 & 0 & 0 \\
\hline Oxytetracycline & 1 & 100 & 0 & 0 & 0 & 0 \\
\hline Amoxicillin & 0 & 0 & 0 & 0 & 1 & 100 \\
\hline Ampicillin & 0 & 0 & 1 & 100 & 0 & 0 \\
\hline
\end{tabular}

strains were sensitive to two antimicrobials (fosfomycin and colistinsulphate) and resistant to six antibiotics (erythromycin, streptomycin, doxycycline, clindamycin, amoxicillin and ampicillin) with percentage 100\%. While two $E$. coli strains were sensitive to three antibiotics (doxycycline, ciprofloxacin and oxytetracycline) and resistant to two antimicrobials (trimethoprim and gentamycin) with percentage $66.6 \%$. In addition, only one $E$. coli strain was sensitive to two antibiotics (trimethoprim and gentamycin) and resistant to two antibiotics (ciprofloxacin and oxytetracycline) with a percentage $33.3 \%$ (Table 5). Ezzeldeen et al. (2014) isolated 13 E. coli strains from chicken meat with incidence $32.5 \%$ and these strains were highly resistant $(100 \%)$ to ten antibiotics (erythromycin, amoxicillin, ampicillin, oxytetracycline, vancomycin, clauvinic acid, penicillin, chloramphenicol, ciprofloxacin and trimethoprim) and variable resistant against gentamicin (92.3\%), norfloxacin (84.6\%) and nalidixic acid $(53.8 \%)$.

S. kentucky strain isolated from frozen chicken meat thawed over counter-top was sensitive to eight antimicrobials (streptomycin, doxycycline, trimethoprim, fosfomycin, ciprofloxacin, gentamycin, colistin sulphate and oxytetracycline) and resistant to three antibiotics (erythromycin, clindamycin and amoxicillin) (Table 6). However, Moawad et al. (2017) isolated one strain of $S$. kentucky from chicken meat with incidence $6.7 \%$ and found that this strain was resistant to six antimicrobials (amoxycillin, streptomycin, trimethoprim, ampicillin, nalidixic acid and tetracycline) and sensitive to only colistin.

\section{Conclusion}

From the current study it could be concluded that lowest bacterial counts (total aerobic mesophilic bacterial count and total Coliforms) were recorded in samples thawed in microwave. However, the highest total Coliforms counts were observed in samples thawed over the counter-top. In addition, food borne pathogens such as Staph. aureus, E. coli poly $y_{2} O_{125}$, E. coli poly ${ }_{2}: O_{44}$ and $S$. kentucky were isolated only from samples thawed over the counter-top with incidence $20 \%, 6.67,13.33$ and $6.67 \%$, respectively. The results of sensitivity test showed that all isolated strains were resistant to amoxicillin and sensitive to fosfomycin. Therefore, from the current study it could be recommended the use of microwave as a fast, suitable and safe way for thawing of frozen poultry carcasses followed by the use of refrigerator provided that in case of using the microwave the thawed chicken carcasses should be cooked immediately meanwhile, refrigerator can be used if the planning on serving these foods not immediately. However, thawing over counter-top is inappropriate method which affects safety and quality of thawed meat.

\section{Author's Contribution}

FAMEN conceived and designed the study and supervised the study. HHSAN participated in the experiments, acquisition, data analysis and interpretation and writing the manuscript. DHM and HBM collected the samples and participated in the experiments. All authors approved the final version of the manuscript.

\section{REFERENCES}

Abou-Hussein RAA, 2007. Detection of food mediated pathogens in some meat and chicken products by using recent techniques. PhD, Thesis, Faculty of Veterinary Medicine, Zagazig University, Moshtohor, Benha, Egypt.

Akhtar S, Khan MI and Faiz F, 2013. Effect of thawing on frozen meat quality: A comprehensive review. Pakistan Journal of Food Science 23: 198-211.

Akhtar S, Khan MI and Faiz F, 2013. Effect of thawing on frozen meat quality: A comprehensive review. Pakistan Journal of Food Sciences 23: 198-211.

Ambrosiadis I, Theodorakakos N, Georakis S and Lekas S, 1994. Influence of thawing methods on the quality of frozen meat and drip loss. Fleischwirtschaft, 74: 284-286.

Belletti N, Kamdem SS, Patrignani F, Lanciotti R, Covelli A and Gardin F, 2007. Antimicrobial activity of aroma compounds against Saccharomyces cerevisiae and improvement of microbiological stability of soft drinks as assessed by logistic regression. Applied and Environmental Microbiology 73: 5580-5586. https://doi.org/10.1128/AEM.00351-07

Bosco AD, Mugnai C, Mattioli S, Rosati A, Ruggeri S, Ranucci D and Castellini C, 2016. Transfer of bioactive compounds from pasture from meat to organic free-range chickens. Poultry Science 95: 2464-2471. https://doi.org/10.3382/ ps/pev383

EFSA "European Food Safety Authority" 2013. EFSA panel on biological hazards (BIOHAZ) panel: scientific opinion on the risk posed by pathogens in food of non-animal origin. EFSA Journal 11: 3025-3163. https://doi.org/10.2903/ j.efsa.2013.3025

El Jalil MH, Khamar M, Maaninou S, Dahha M, Zinedine A and Ameur N, 2020. Antibiotic resistance of Escherichia coli strains isolated from broiler meat in Morocco. International Journal of Veterinary Science 9: 305-308.

Erdem AK, Saglam D, Ozer D and Ozcelik E, 2014. Microbiological quality of minced meat samples marketed in Istanbul. YYU Veteriner Fakultesi Dergis 25: 67-70.

ES 1090/2005. Public Safety Standards: Frozen Poultry and Rabbits. Egyptian Organization for Standardization and Quality Control, Arab Republic of Egypt. https://law.resource.org/pub/eg/manifest.eg.html

ES 1651/2005. Egyptian Standards for Chilled Poultry and Rabbits: Egyptian Organization for Standardization and Quality Control. Ministry of Industry, Arab Republic of Egypt, Cairo, Egypt.

Ezzeldeen NA, Al-Amary KF, Abdelmonem MA, Abd El-Moez SI and Abdelaziz MF, 2014. Genotyping characterization of E. coli Egyptian isolates with special reference to drug resistance genes. Journal of Middle East and North Africa Animal Science 1: 176-207. 
Farber JM, Aoust JYD, Diotte M, Sewell A and Daley E, 1998. Survival of Listeria spp. on raw whole chickens in microwave ovens. Journal of Food Protection 61: 14651469. https://doi.org/10.4315/0362-028X-61.11.1465

Gilbert SE, Whyte R, Bayne G, Paulin SM, Lake RJ and Logt P, 2007. Survey of domestic food handling practices in New Zealand. International Journal of Food Microbiology 117: 306-311. https://doi.org/10.1016/j.ijfoodmicro.2007.05.004

Hassanien FM, El-Sabagh RA, Nassief MZ and Refat MS, 2016. Bacterial and chemical quality of frozen chicken meat received at governmental hospital modern. Benha Veterinary Medicine Journal 30: 109-117. https://doi.org/10.21608/ bvmj.2016.31355

He X, Liu R, Nirasawa S, Zheng D and Liu H, 2013. Effect of high voltage electrostatic field treatment on thawing characteristics and post-thawing quality of frozen pork tenderloin meat. Journal of Food Engineering 115: 245-250. https://doi.org/10.1016/j.jfoodeng.2012.10.023

ICMSF "International Commission and Microbiological Specification for Foods" 1980. Microbial ecology of foods. Vol. 1, Academic Press, New York, Toronto.

Islam NN, Akter M, Farzana Z, Kader AJBN, Uddin I, Siddiki AMAMZ and Kamaruddin KM, 2014. Detection of Staph. aureus in frozen chicken rinse through bacteriological and nuc gene specific PCR methods and their drug resistance patterns in southern chittagong, Bangladesh. Research Journal of Microbiology 9: 251-264. https://doi.org/ $10.3923 / \mathrm{jm} .2014 .251 .264$

ISO 4832, 2006. Horizontal method for the enumeration of Coliforms - colony count technique International organization for standardization. Geneva, Switzerland.

ISO 4833, 2013. Microbiology of food and animal feeding stuffs -horizontal method for the enumeration of microorganismscolony-count technique at $30^{\circ} \mathrm{C}$. International organization for standardization. Geneva, Switzerland.

ISO 6579, 2002. Microbiology of food and animal feeding stuffs -horizontal method for the detection of Salmonella. International organization for standardization. Geneva, Switzerland.

ISO 6888, 2018. Microbiology of food and animal feeding stuffs - horizontal method for enumeration of coagulase - positive staphylococci (Staph. aureus and other species). International organization for standardization. Geneva, Switzerland.

Jamshidi A, Seifi HA and Kooshan M, 2010. The effect of shorttime microwave exposures on E. coli $\mathrm{O}_{157}: \mathrm{H}_{7}$ inoculated onto beef slices. African Journal of Microbiology Research 4: 2371-2374.

Koneman EW, Allen SD, Sowell VR and Sommers HM, 1979. Color atlas and textbook of diagnostic microbiology. J.B. Lippincott Company, Philadelphia. Toronto. Journal of Infectious Diseases 123: 97-98.

Krieg NR and Holt JG, 1984. Bergey's Manual of Systematic Bacteriology. Vol. 1, Williams and Willkins Baltimore, USA.

Krifi B, Amine M and Makram J, 2014. Microbiological comparison of microwave and traditional thawing processes for poultry meat. African Journal of Microbiology Research 8: 109-117. https://doi.org/10.5897/AJMR2013.5734
Leygonie C, Britz TJ and Hoffman LC, 2012. Impact of freezing and thawing on the quality of meat. Meat Science 91: 93-98. https://doi.org/10.1016/j.meatsci.2012.01.013

Mansouri LN, 2012. The effect of various methods of defrosting on microbial contamination of frozen banana shrimp (Penaeusmerguiensis). Asian Pacific Journal of Tropical Biomedicine 2: 1888-1891. https://doi.org/10.1016/S22211691(12)60515-2

Mehmood K, Bilal RM and Zhang H, 2020. Study on the genotypic and phenotypic resistance of tetracycline antibiotic in Escherichia coli strains isolated from free ranging chickens of Anhui Province, China. Agrobiological Records 2: 63-68. https://doi.org/10.47278/ journal.abr/2020.014

Met A, Çelik A, Öncül AT and Hocaoğlu S, 2013. Investigation of different thawing methods combined with freezing rate on slab shape meat quality. 59th International Congress of Meat Science and Technology, Izmir, Turkey.

Moawad AA, Hotzel H, Awad O, Tomaso H, Neubauer H, Hafez $\mathrm{HM}$ and El-Adawy H, 2017. Occurrence of S. enterica and E. coli in raw chicken and beef meat in northern Egypt and dissemination of their antibiotic resistance markers. Gut Pathogens 9: 1-13. https://doi.org/10.1186/s13099-017-206-9

Oliveira MR, Gubert G, Roman SS, Kempka AP and Prestes RC, 2015. Meat quality of chicken breast subjected to different thawing methods. Brazilian Journal of Poultry Science 17: 165-172. https://doi.org/10.1590/1516-635x1702165-172

Orlova D, Kalyuzhnaya T, Tokarev A and Kuznetsov Y, 2020. New method for Veterinary and sanitary control of defrosted meat and fish. International Journal of Veterinary Science 9: 317-319.

Ordóñez JAP, Rodríguez MIC, Álvarez LF, Sanz MLG, Minguillón GGF, Perales LH and Cortecero MDS, 2005. Tecnologia de alimentos-Alimentos de Origem Animal. Vol 2, Pp. 279, Artmed, Porto Alegre.

Schnepf M and Barbeau W, 2007. Survival of $S$. Typhimurium in roasting chickens cooked in a microwave, convection microwave and conventional electric oven. Journal of Food Safety 9: 245-252. https://doi.org/10.1111/j.1745-4565. 1989.tb00524.x

Sulleyman KW, Adzitey F and Boateng EF, 2018. Knowledge and practices of meat safety by meat sellers in the Accra Metropolis of Ghana. International Journal of Veterinary Science 7: 167-171.

Woo IS, Rhee IK and Park HD, 2000. Differential damage in bacterial cells by microwave radiation on the basis of cell wall structure. Applied and Environmental Microbiology 66: 2243-2247. https://doi.org/10.1128/AEM.66.5.2243-2247. 2000

Xia X, Kong B, Liu J, Diao X and Liu Q, 2012. Influence of different thawing methods on physicochemical changes and protein oxidation of porcine longissimus muscle. LWTFood Science and Technology 46: 280-286. https://doi.org/ 10.1016/j.lwt.2011.09.018

Zhang X, Gao T, Song L, Zhang L, Jiang Y, Li J, Gao F and Zhou G, 2017. Effects of different thawing methods on the quality of chicken breast. International Journal of Food Science and Technology 52: 2097-2105. https://doi.org/10.1111/ijfs. 13488 